\title{
THE NATURAL DYES EXTRACTED IN SÃO JOÃO DE CÔRTES, ALCÂNTARA, MARANHÃO: AN APPROACH ORIENTED TO SUSTAINABLE DESIGN
}

\section{OS CORANTES NATURAIS EXTRAÍDOS EM SÃO JOÃO DE CÔRTES, ALCÂNTARA, MARANHÃO: UMA ABORDAGEM ORIENTADA PARA O DESIGN SUSTENTAVEL}

\section{Cláudia do Rosário Matos Nogueira, (UFMA) Raquel Gomes Noronha, PhD (UFMA) Denilson Moreira Santos, PhD (UFMA)}

\section{Key Words}

Sustainability; Natural dyes; Territorial design; Identity

\author{
Palavras Chave \\ Sustentabilidade; Corantes naturais; Design territorial; Identidade
}

\begin{abstract}
This article discusses the obtainment of natural dyes in São João de Côrtes, Alcântara, Maranhão, extracted from annatto (Bixa Orellana), serrette (Byrsonima Basiloba), red mangrove (Rhizophora Mangle), saffron (Curcuma Longa), genipap (Genipa Americana) and wild indigo (Indigofera Suffruticosa). As an objective, this article proposes a course to discuss aspects of territorial design and to investigate the processes of obtaining the natural dyes from the aforementioned community, emphasizing sustainability. As far as methods, there is a description of the traditional techniques used by residents of the said village for the production of natural dyes, forming a qualitative research with an ethnographic approach which features interaction with the community through interviews with indirect questions, footage and photographs. As for results, there are: the discussion and reflection on the activities of obtaining the natural dyes through the ethnographic experiences presented with the intention of valuing a territory.
\end{abstract}

\section{RESUMO}

Este artigo discute a obtenção de corantes naturais em São João de Côrtes, Alcântara, Maranhão, extraídos do urucum (Bixa Orellana), murici do mato (Byrsonima Basiloba), mangue vermelho (Rhizophora Mangle), açafrão (Curcuma Longa), jenipapo (Genipa Americana) e anil (Indigofera Suffruticosa). Como objetivo, este artigo propõe um percurso para se discutir aspectos de design territorial e investigar os processos de obtenção dos corantes naturais da citada comunidade, enfatizando a sustentabilidade. No que diz respeito aos métodos, há uma descrição das técnicas tradicionais utilizadas pelos moradores da referida vila para a produção de corantes naturais, caracterizando uma pesquisa qualitativa com uma abordagem etnográfica, apresentando interação com a comunidade através de entrevistas com perguntas indiretas, imagens e fotografias. Como resultados têm-se um debate e reflexões a respeito das atividades de obtenção dos corantes naturais por meio das experiências etnográficas, na intenção de valorizar um território. 


\section{INTRODUCTION}

The demands and concerns of sustainability in the contemporary world have made humankind turn its attention to the old techniques of material production and create a new scenario in which there are creative solutions to problems, with technical and rational procedures. Adelia Borges adds that "old techniques of using natural dyes in the dyeing of raw materials, which had been abandoned in favor of industrial dyes, have come to be recovered." (BORGES, 2011, p. 61).

According to Manzini (2008, p. 15), what is intended is "the preservation and regeneration of our environmental and social capital", in an effort to try out new lifestyles and recover processes of production and consumption. In addition, health concerns, with the possible harm that synthetic man-made dyes (toxicological hazards, for example) can cause to humans, also appear as ways of justifying growing research on the use of natural dyes (SABRÁ, 2012).

Krucken (2009) comments that there is a demand for healthy products and a history to tell that is traceable. The designer, in this context, perceives and acts to solve the needs of these new perspectives of values and qualities, and for that, according to Krucken, Oliveira and Silva (2014) some processes in which this professional can give support are set: in the identification of the potentials of local resources and skills for sustainable production; in the strengthening of the sense of belonging of the processes by the community, as well as in promoting the dialogue between tradition and innovation; and in the strengthening of the image of the product and its territor'y.

In this sense, one of the great challenges of design is to make the processes and systems around us intelligible, revealing and comprehensible (THACKARA, 2008). In this way, the objective of this article is to propose a course for the analysis of the obtainment and use of the natural dyes from São João de Côrtes (Alcântara, Maranhão), an old village of fishermen and naval carpenters.

\section{THEORETICAL-METHODOLOGICAL ASPECTS}

The course chosen for this study should follow the reflections of Canclini (1983), when speaking of how things have life and stories to tell, and of Clifford (1997) commenting that one must be present at a specific place for research, being a descriptive of techniques applied and transmitted by generations, rituals and the cosmology employed by residents of the village in question, characterizing it as qualitative research with an ethnographic approach, in which an appropriate way of interacting with the community is recommended: through interviews with indirect questions, photographs and filming involving the people who extract and produce the natural dyes.

Using holistic vision, about the analysis intense and direct will allow comprehending and relating the daily about the research problem, always for better relation between the researcher and the researched group by a trust relationship. It will result in the description of the most relevant aspects for the research.

Rocha and Eckert (2008, p. 2) explain that for ethnographic research to happen, direct observation "is undoubtedly the privileged technique for investigating knowledge and practices in social life." The researchers made visits to the community of São João de Côrtes to meet the residents and the daily life of the village.

In one of the visits it was possible to accompany one of the interviewees, Valdecy Nogueira, known as Paco, to the areas where raw materials are extracted to obtain the natural dyes. In these investigations to researchers obtained much information about the old techniques passed by several generations, as well as on the characteristics of the vegetables used, whose data are part of the empirical knowledge of the residents. Paco explained at the time that the people who collect the materials need to be in tune with nature, respecting their cycles (Figure 01 and Figure 02)

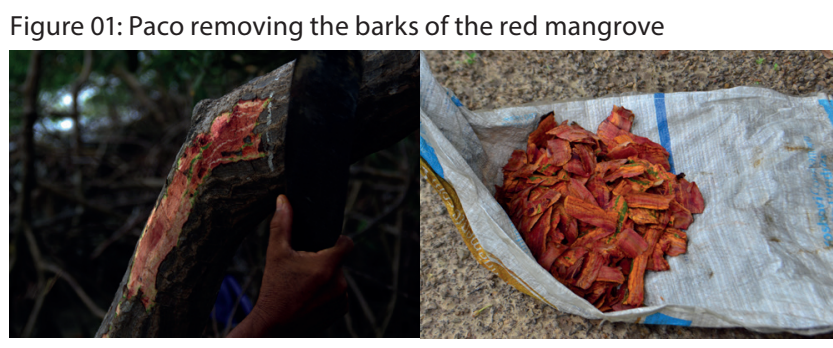

Source: The authors of the research

Figure 02: Selection of the roots of saffron for the yellow dye and Paco explaining how to remove banana or Barbados nut sap

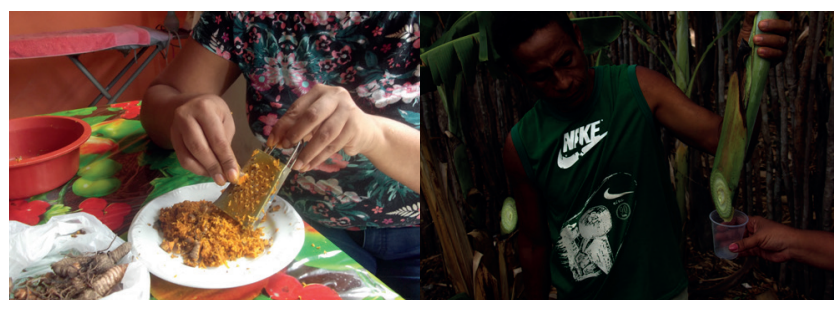

Source: The authors of the research

The designer, as a professional working in a world open to diversities, comes into contact with the cultural manifestations of various communities. This professional needs to be attentive, because "in this contemporary and 
hypermodern world, not everything is high tech" (IBARRA, RIBEIRO, 2014, p.10), justifying the valuing of the material and symbolic manifestations of a Maranhão community. In the words of Noronha (2012), it is necessary to understand the values of artisanal production, the representations and the meanings implicit in their materiality.

The observer connects themselves in a visual, tactile, olfactory and auditory way with the flows, with the movements of the environment, being interested in how the materials can interact with the people and vice versa. Thus, the researcher has to abandon their intellectually sovereign position and "feel the world" (INGOLD, 2013, p.320). From these theoretical and methodological perspectives, it is going to be showed the main steps done to realize the research (Table 01).

Table 01: Table with the main steps done to realize the research.

\begin{tabular}{|c|c|c|}
\hline STAGE & OBJECTIVE & SCHEDULE \\
\hline $\begin{array}{l}\text { Bibliography } \\
\text { review }\end{array}$ & $\begin{array}{l}\text { Survey research } \\
\text { about nature } \\
\text { dye, design, } \\
\text { territory, and } \\
\text { Sustainability. }\end{array}$ & $\begin{array}{l}\text { From June } \\
2016 \text { to April } \\
2017 .\end{array}$ \\
\hline Survey & $\begin{array}{l}\text { Realize a } \\
\text { mapping about } \\
\text { the vegetation } \\
\text { used for } \\
\text { dyeing. }\end{array}$ & $\begin{array}{l}\text { November } \\
2016 .\end{array}$ \\
\hline $\begin{array}{l}\text { Initial } \\
\text { Systematizatio } \\
\mathrm{n}\end{array}$ & $\begin{array}{l}\text { Initials tests for } \\
\text { dye } \\
\text { production; } \\
\text { identifying } \\
\text { plants used in } \\
\text { SJC. }\end{array}$ & $\begin{array}{l}\text { January } \\
2017 .\end{array}$ \\
\hline Ethnography & $\begin{array}{l}\text { Daily } \\
\text { observation } \\
\text { from the } \\
\text { village, } \\
\text { watching } \\
\text { discourses and } \\
\text { native practices } \\
\text { (three visits). }\end{array}$ & $\begin{array}{l}\text { From } \\
\text { November } \\
2016 \text { to April } \\
2017 .\end{array}$ \\
\hline $\begin{array}{l}\text { Classification } \\
\text { and data } \\
\text { analyze }\end{array}$ & $\begin{array}{l}\text { Making tests } \\
\text { from materials } \\
\text { and } \\
\text { information } \\
\text { collected in } \\
\text { field. }\end{array}$ & $\begin{array}{l}\text { From April to } \\
\text { May } 2017 .\end{array}$ \\
\hline $\begin{array}{l}\text { Results and } \\
\text { discussions }\end{array}$ & $\begin{array}{l}\text { Systematizatio } \\
\mathrm{n} \text { from results. }\end{array}$ & $\begin{array}{l}\text { From April to } \\
\text { May } 2017 .\end{array}$ \\
\hline
\end{tabular}

Source: The authors of the research

\section{DESIGN AND SUSTAINABILITY: ASPECTS ABOUT NATURAL DYES}

Thackara (2008) mentions the concern of environmentalists about responsibilities, but they hardly ever question themselves about the possibilities in sustainable production. The designer, on the other hand - in addition to imagining products and systems that cater to symbolic, functional and aesthetic issues - aims at sustainability in their projects. It is worth remembering that sustainable products do not only meet environmental criteria, but also economic and social requirements. Manzini (2008) emphasizes that design has the ability to generate visions of a sustainable sociotechnical system; organize them into a coherent system of regenerative products and services, sustainable solutions; and communicate such visions and systems appropriately so that they are recognized and evaluated by a sufficiently broad public able to apply them effectively (MANZINI, 2008, p.28).

According to Rodrigues (2013), the designer committed to sustainability considers the whole life cycle of a product, i.e. what happens during the extraction of the raw material, the stages of production and use, and how its discard is done. Manzini $(2008$, p.12) explains that "today, sustainability should be the goal of all possible design research". In addition to these issues, the designer needs to be aware of the possibilities of products derived from the symbolic and material manifestations of a community, such as the production of natural dyes by villages, often forgotten by the Brazilian population in general, such as the São João de Côrtes community, whose work with the extraction of plant dyes is passed down from generation to generation.

Natural products are questioned about their quality and durability; however, it is understood that users of this type of product have knowledge about their characteristics and certainly value them precisely for their structure. The use of natural dyes has been vehemently investigated, "especially after talks about sustainability and strategies to achieve it arose" (RODRIGUES, 2013, p.18). Krucken (2010) adds still that action planning needs to be done by bringing together social and territorial capital that propose sustainable and sustainable consumption ideas. Health also appears as another justification for these investigations:

The toxicological risks of synthetic dyestuffs to human health are intrinsically related to the mode and time of exposure [...], oral ingestion, skin sensitization, sensitization of the respiratory tract (CLARKE, 1995 apud SABRÁ, 2012, p.88). 
There is a great current interest in studying the possibilities of using natural dyes in Brazil. Sabrá (2012, p. 87) names some factors for this motivation: complex biodiversity, making it possible to obtain a large and varied range of substances to be used as pigments, dyes or paints; Differentiation of products through innovation and search for new ingredients. In this case, natural dyes can add value to the final products and be an alternative way of generating work and income, especially in communities in the interior of the country or in the textile, cosmetics, food, etc. industries.

\section{DISCUSSIONS AND RESULTS}

The use of natural dyes, thus, is in accordance with what Manzini $(2008$, p.16) presents about the role of the designer. Designers, according to the author, even without imposing their ideas, have "tools to operate on the quality of things and their acceptability". In other words, the work of the designer is aims to develop the image of the product and its place of origin, that is, it is necessary to follow the path, the chain of materials, because materiality is not an attribute, but a story (INGOLD, 2011).

Local products, in agreement with Krucken (2010), are the result of work carried out over time, where resources of the biodiversity, customs and habits of a given population are involved. The author mentioned enriches this thinking by defining terroir as: a territory characterized by interaction with man over the years, whose resources and products are strongly determined by the cultural, soil and climate conditions".

The cultural aspects present in the products determine their demand; in their specificities, in their authenticity. Thackara $(2008$, p. 13) complements this thought by stating that "we are resuming appreciation and respect for what people are capable of doing and technology isn't". Krucken (2009, p.14) contributes by stating that "the need for a change in lifestyle and productive models to reduce environmental impact is increasingly evident".

One can learn several lessons with the human being: the creation of products for its own use has always existed, and this is the case of the natural dyes made in the community of São João de Côrtes in Alcântara. In this village of fishermen, of indigenous origin, there is knowledge passed down through several generations, of techniques of painting the sails and waterproofing of their boats, of the puçá (a type of sieve or net for catching small fish) used in the fisheries, with products taken from the nature. In this example, the designer has much more to do with the community than the other way around.
Certainly, the techniques of extraction and production of plant dyes and the importance of color in the products were apprehended with the indigenous ancestors of this community, as Proença $(2003$, p.195) specifies: "The colors most used by the Indians to paint their bodies are the very lively red of annatto, the black of the genipap juice ink, and the white of the tabatinga (a type of clayey stone)".

These dyes extracted in the aforementioned village are strongly related to the conditions of the climate, the soil, but also the cultural manifestations of the community. However, it is necessary to agree with Ingold (2013) that the techniques are not passively transmitted, because the information passed by generations make way to knowledge, which can be taken forward with an artisan's own context, know-how, and life story. Thus, it is not just about reduplication, but about the particularities of repetition in tune with the rhythms of the environment.

Those who know the techniques know exactly when and where to extract materials to obtain the natural dyes, as well as obey the supernatural aspects that govern these activities. That is, the products taken from nature of this village, such as the example of the production of the orange dye from the annatto, are beyond their physical materiality, but with aggregate immaterial values.

The images present the selection of the seeds of the annatto and then washed with water to obtain the natural dye (Figure 03).

Figure 03: Manipulation of annatto seeds for the production of orange dye

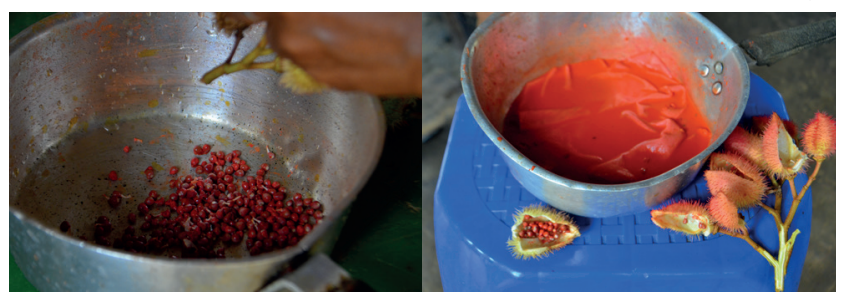

Source: photos by Lucilene Pereira for research

A visit to the extraction areas to identify the plants from which the dyes originate and the techniques for their obtainment was scheduled with the farmer Paco during a visit to São João de Côrtes which took place between December 3rd and 5th, 2016. He explained that the activities of naval carpentry and natural dyeing are essentially masculine, in which knowledge is clearly empirical, passed down by generations and of indigenous origin, but that almost all the inhabitants of the village, especially the oldest ones, know the techniques of production of natural dyes. 
In the visit to the field of research with Paco (information collected during field research conducted on December 4th, 2016) it was possible to identify the serrette, (from which one obtains red dye and a type of natural varnish), annatto (orange dye), red mangrove (red dye and natural varnish) and saffron (yellow dye).

The farmer explained that it was not a good time for the production of the black dye of genipap and the blue dye of wild indigo, whose plantation exists but must be mowed so that the plants reappear. Thus, in another visit, at an appropriate time, it will be possible to verify the techniques of obtaining the black and blue dyes.

Basically, barks from the serrette trunk and the root of the red mangrove are removed, and are then soaked in a container with water, for about three days, for the red dye to release. Paco emphasized that older plants provide a darker red dye and that it is common to add a few drops (depending on the amount of dye required) of banana or Barbados nut sap for better fixing of the dyes. From annatto, orange color is produced when the seeds of the fruit are dipped in water; and from saffron one obtains yellow when shavings of its roots are put into water.

During the aforementioned visit, it was observed that it is relevant to preserve the natural cycles of ecosystems. Paco reported that the raw material for the production of natural dyes can be extracted at any time of year, but according to the farmer, the rainy season (between December and April or May) favors the development of plants, as well as the movements of the Moon which interfere in the production of banana and Barbados nut sap ("milk"). In addition, due to popular belief, Paco believes that "there are people who are not good at milking" plants and that it is necessary to observe these conceptions about the relation between man and nature.

Another source of discussion for designers: in São João de Côrtes, what Canclini (1983) observed when he mentioned the changes that sometimes occur with rudimentary techniques, in which the younger craftsmen are leaving the activities in the yards in search of the improvement of life in other work possibilities, is currently happening. As a result, the larger ships that are made to use sails are no longer produced, since they require a lot of time for their construction and more people involved in the process, and naval carpentry is practically in the hands of old craftsmen (who are limited to making canoes).

In this way, the techniques of the extracting natural dyes that colored the sails of these boats are bound to fall into oblivion. Therefore, a cultural policy that preserves the tradition of this craft and the conservation of the workers in its territory must be carried out; this decision must, however, democratically involve the artisans themselves.

Initial investigations of these products led to a table (Table 02) that relates the plants to the obtained colors and varnishes, providing elements for the construction of a color chart. It was also sought to investigate how these plants are known scientifically.

Table 02: Table with the plants and the colors obtained from them

\begin{tabular}{|l|l|l|}
\hline \multicolumn{1}{|c|}{ PLANT } & SCIENTIFIC NAME & \multicolumn{1}{|c|}{$\begin{array}{c}\text { OBTAINED } \\
\text { RESULT }\end{array}$} \\
\hline Genipap & Genipa Americana L. & Black dye \\
\hline Annatto & Bixa Orellana L. & Orange dye \\
\hline Serrette & Byrsonima Basiloba & $\begin{array}{l}\text { Natural varnish } \\
\text { Dark red dye }\end{array}$ \\
\hline $\begin{array}{l}\text { Red } \\
\text { Mangrove }\end{array}$ & Rhizophora Mangle & $\begin{array}{l}\text { Red dye } \\
\text { Natural varnish }\end{array}$ \\
\hline Saffron & Curcuma Longa & Yellow dye \\
\hline Wild Indigo & Indigofera Suffruticosa & Blue dye \\
\hline
\end{tabular}

Source: Table created by the authors based on information by Harri Lorenzi, 2014 ; Etno Botânica, 2016 and the villagers

Given this information, it is clear that designers can make the story behind the plant dyes from São João de Côrtes visible to users who are interested in products with sustainable qualities. This information can be on labels and packaging, for example. The previous reflections extend possibilities for the work of the designer, who can intervene in the clarifications between scientific and popular knowledge, as well as awaken the interest of the communities to act according to the demands of a consumer market eager to get in touch with differentiated products with sustainable qualities, as can be seen in the growing study on the feasibility of using natural dyes on fabrics in the fashion textile industry (RODRIGUES, 2013).

In the case of São João de Côrtes, investments in the obtainment of knowledge can turn the attention of the community to a possible alternative form of income, returning to a traditional activity, directing the concentration in the purpose of addressing the issues of revaluation of knowledge about the production of natural dyes by the villagers, directing the look at identities, as well as to verify the solidity of these products, the quantities of materials for dyeing and the construction of a color chart. 


\section{FINAL CONSIDERATIONS}

The present article presented exploratory aspects and results of interviews with residents of São João de Côrtes, holders of techniques for the production of natural dyes, in order to expose a path of identification and use of these materials. The designer, in this way, participates as a transmitter of strategies for the development of sustainable products and services, in a constant dialogue between tradition and innovation. The practice of Design allied to Ethnography is relevant when evaluating and exploring the materiality of a region. It is known, however, of the care and criteria to be considered in a research with communities. The presence of the researcher in the field, with a theoretical load on the subjects that involve the investigations, must be based on the most appropriate approaches for each group of individuals.

Brazil, as a potential supplier of materials that serve a market that increasingly values natural products, needs to promote studies aimed at this aspect. The complex production of materials by remote locations reminds us of the need for research in the world of environmental and social relations in these communities. In this article, reflections were made from narratives and the observation of the practices of obtaining the natural dyes with emphasis on the traditional knowledge transmitted by generations in São João de Côrtes. Extraction activities of natural materials are carried out by men, of which many are linked to the work in the fields of agriculture, fishing and artisanal naval carpentry.

In a field survey in São João de Côrtes, the farmer Paco explained how the production of the natural dyes of the place happens and the importance in respecting the cycles of nature for the acquisition of these materials, showing satisfaction when talking about his life experiences and the skills acquired with his ancestors. He also followed the researchers to the field of work, where one could observe the selection of the plants, how the raw materials (bark, seeds, and roots) are extracted and how the dyes are obtained, as well as the knowledge about color fixation.

The theoretical basis of this article presented the importance of the designer's work for the issues of traditional knowledge and territory, especially with design strategies that value the story implicit in the dyes produced following the indigenous descendants of the mentioned village in mind. Thus, a direction to the continuity of these activities is proposed, to the relevance of natural resource management, avoiding the exhaustion of these sources, establishing an identity relationship with residents of the researched community and with the work of obtaining these materials.

\section{ACKNOWLEDGMENTS}

The authors are grateful for the participation of NIDA (Nucleus of Research in Innovation, Design and Anthropology), UFMA, and FAPEMA (TECS-01171/2015) in the logistics that made field research possible.

\section{REFERENCES}

BORGES, Adelia. Design + Artesanato: o caminho brasileiro. São Paulo: Terceiro Nome, 2011.

CANCLINI, Néstor Garcia. As culturas populares no capitalismo. São Paulo: Editora Brasiliense, 1983.

CLIFFORD, James. Routes: travel and translation in the twentieth century. Cambridge: Harvard University Press, 1997.

ETNO BOTÂNICA. Tintas vegetais. Disponível em: <www.etno-botanica.com /2010/05/eber-lopes-ferreira. html>. Acesso em: 20 jul. 2016.

IBARRA, Maria Cristina; RIBEIRO, A. C. O design e a valorização do vernacular ou de práticas realizadas por não-designers. In: P\&D, 2014, Gramado, Anais... Gramado, 2014.

INGOLD, Tim. Being alive: essays on movement, knowledge and description. Londres e Nova York: Routledge, 2011.

INGOLD, Tim. Making, growing, learning. In: Educação em Revista, v. 29, n.3, set. 2013.

KRUCKEN, Lia. Design e território: valorização de identidades e produtos locais. São Paulo: Studio Nobel, 2009.

KRUCKEN, Lia. No território do design. In: Planeta Sustentável. 2010. Disponível em: <http://planetasustentavel.abril.com.br/noticia/cultura/lia-kruchen-territorio-designlia-kruchen-design-territorio-produto-local-533690.shtml>. Acesso em: 10 jul. 2016.

KRUCKEN, Lia; OLIVEIRA, Paulo Miranda de; SILVA, Elisângela Batista da. Design e território: estudo de iniciativas de valorização da cultura gastronômica. In: Congresso Brasileiro de Pesquisa e Desenvolvimento em Design, 110, 2014. Gramado, Anais... Gramado, 2014. 
LORENZI, Harri. Árvores brasileiras: manual de identificação e cultivo de plantas arbóreas nativas do Brasil. v.1. São Paulo: Plantarum, 2014.

MANZINI, E. Design para a inovação social e sustentabilidade: comunidades criativas, organizações colaborativas e novas redes projetuais. Rio de Janeiro: E-Papers, 2008.

NORONHA, R. G. Sobre a louça, o linho e a rede: processos contemporâneos de construção de valor entre artesãs de Alcântara (MA). In: Revista Pós Ci. Soc. v. 9, n.17, jan/ jun. 2012.

PROENÇA, Graça. História da arte. São Paulo: Ática, 2003.

ROCHA, Ana Luiza Carvalho da; ECKERT, Cornelia. Etnografia: saberes e práticas. In: Ciências Humanas: pesquisa e método. Porto Alegre: Editora da Universidade, 2008.

RODRIGUES, J. A. R. Uso de corantes naturais no tingimento de artigos têxteis de moda. 2013.128 f. Dissertação (mestrado) - Escola de Artes, Ciências e Humanidades, Universidade de São Paulo, São Paulo, 2013.

SABRÁ, Flávio (org.). Inovação, estudos e pesquisas: reflexões para o universo têxtil e de confecções. Rio de Janeiro: SENAI/CETIQT. São Paulo: Estação das Letras e Cores, 2012.

THACKARA, J. Plano B: o design e as alternativas viáveis em um mundo complexo. São Paulo: Saraiva, 2008 
